YOUNG FARMERS' INCOME GENERATING CAPACITY AND CAPITAL REQUIREMENT: CORN PRODUCTION

\author{
Zoltán IstVÁN PrivóCZKI ${ }^{1}$, CSABA BoRbélY ${ }^{2}$, KÁROLY BODNÁR ${ }^{3}$ \\ ${ }^{1}$ Kaposvár University Doctoral (PhD) School of Management and Organizational Science \\ ${ }^{2}$ Kaposvár University Faculty of Economic Science \\ H-7400 Kaposvár, Guba S. u. 40. \\ ${ }^{3}$ University of Szeged Faculty of Agriculture \\ H-6800 Hódmezővásárhely, Andrássy 15. \\ agrarpalyazat@gmail.com
}

\begin{abstract}
The study examines the farms growing on arable crops run by young farmers from economic point of view. The income generating capacity and capital needs of the sectors based on corn cultivation are assessed, while the announced tender scoring system is taken into account. The number of agricultural and horticultural sectors with specialized young plant production farms increased strongly in recent years, so the results of these agricultural businesses have always been and still are in close connection with their production structure. The amount of income on these farms basically depends on the structure of production influenced by the income generating capacity, the capital requirements, the amount of the subsidies and the use of the relations opportunities of the industry. The versatility of the use of corn produces different income generating capability and capital requirements which young farmers can successfully take advantage of during the design and operation period of their enterprises.
\end{abstract}

Keywords: young farmer, corn, income, capital requirement, EUME

\title{
INTRODUCTION
}

In Hungary, the corn has been a crop grown on the largest cultivated area, its area is stable in the average of the past few years it was 1.1-1.2 million ha (Figure 1), however, the national average yield varies greatly. Corn is one of the most important crops, food, animal feed and industrial plants in the world and also in Hungary (MÁRTON, 2015). It occupies $16 \%$ of the world's arable land, (161 million ha), and $27 \%$ of the arable land in Hungary. The total yield of corn production is 820 million tons in the world, and 5-8 million tons in Hungary. Now the corn is grown almost everywhere throughout the world, due to its adaptive properties and the purposeful activity of breeders. The use of corn - both the main and the by-products - is extremely versatile and varied. All over the world and in Hungary as well, mainly it has a part as an energy-rich animal feed, however in the developing countries struggling with problems about $80-90 \%$ of the corn yield is utilized as human food. Corn in animal feed has a significant role in energy supply (FERENCSIK, 2015). It starch content is about $65-70 \%$ starch value $700-800 \mathrm{~g} / \mathrm{kg}$, the energy value $8.5-9.5 \mathrm{MJ} / \mathrm{kg}$ of dry matter.

\section{The use of corn}

In order to analyse the income-generating capacity of the of young farmers' arable crop production we need to clarify the areas where corn is used (Figure 2). 


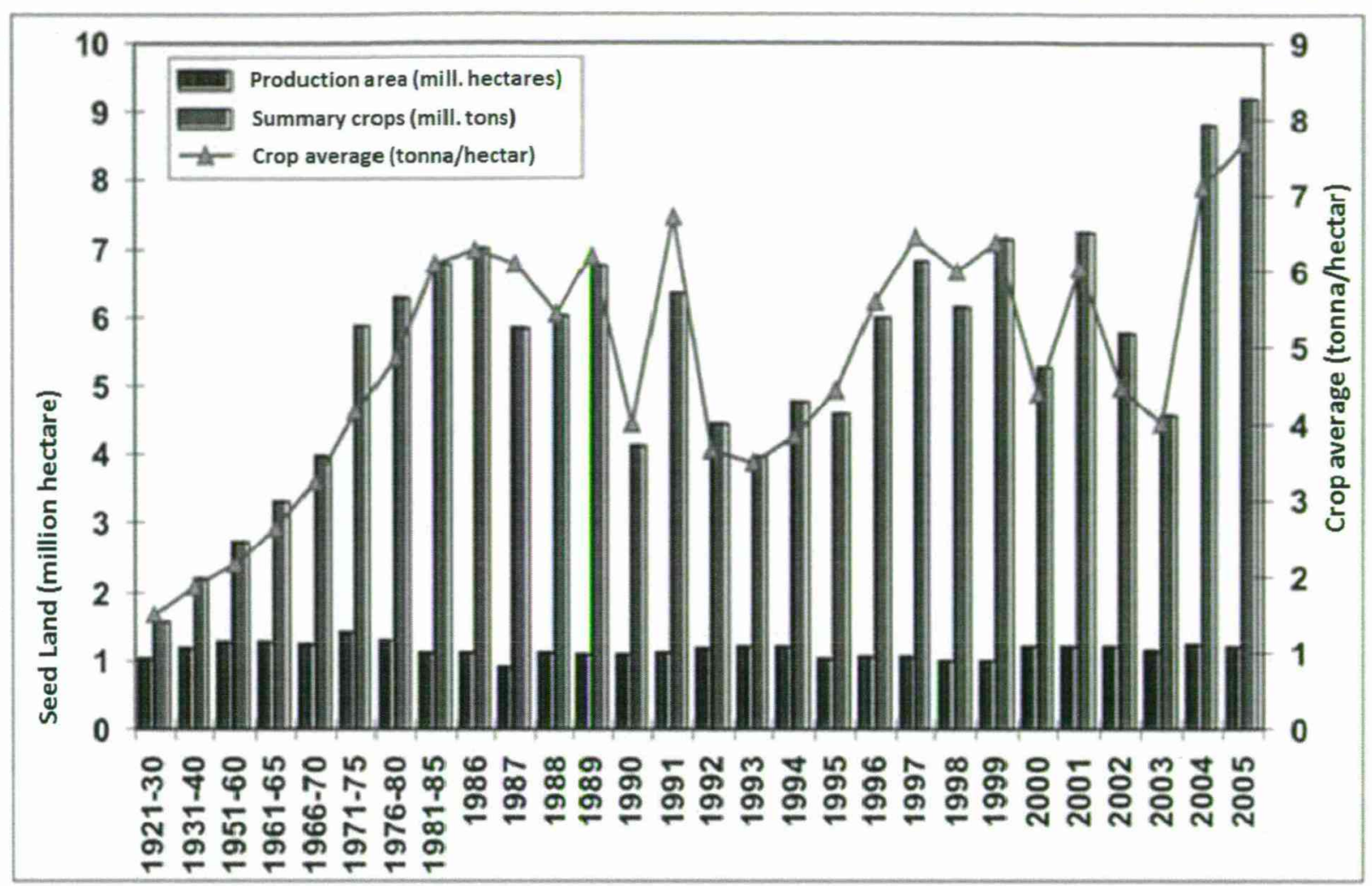

Source: http://www.pointernet.pds.hu

Figure 1. Corn area, average yield and total yield in Hungary between 1921 and 2005

Human nutrition:

- Sweetcorn

- Pop-corn

- Cornmeal, corn flour

Animal feed:

- Mass feed (silage)

- Maize grain

Industrial use:

- Bio ethanol ("High Total Fermentable" hybrids with high starch content)

- Starch

- Corn oil

- Invert sugar

Stem

- Heating

- Incorporated into the soil as a nutrient (ANTAL ET AL, 2005) 


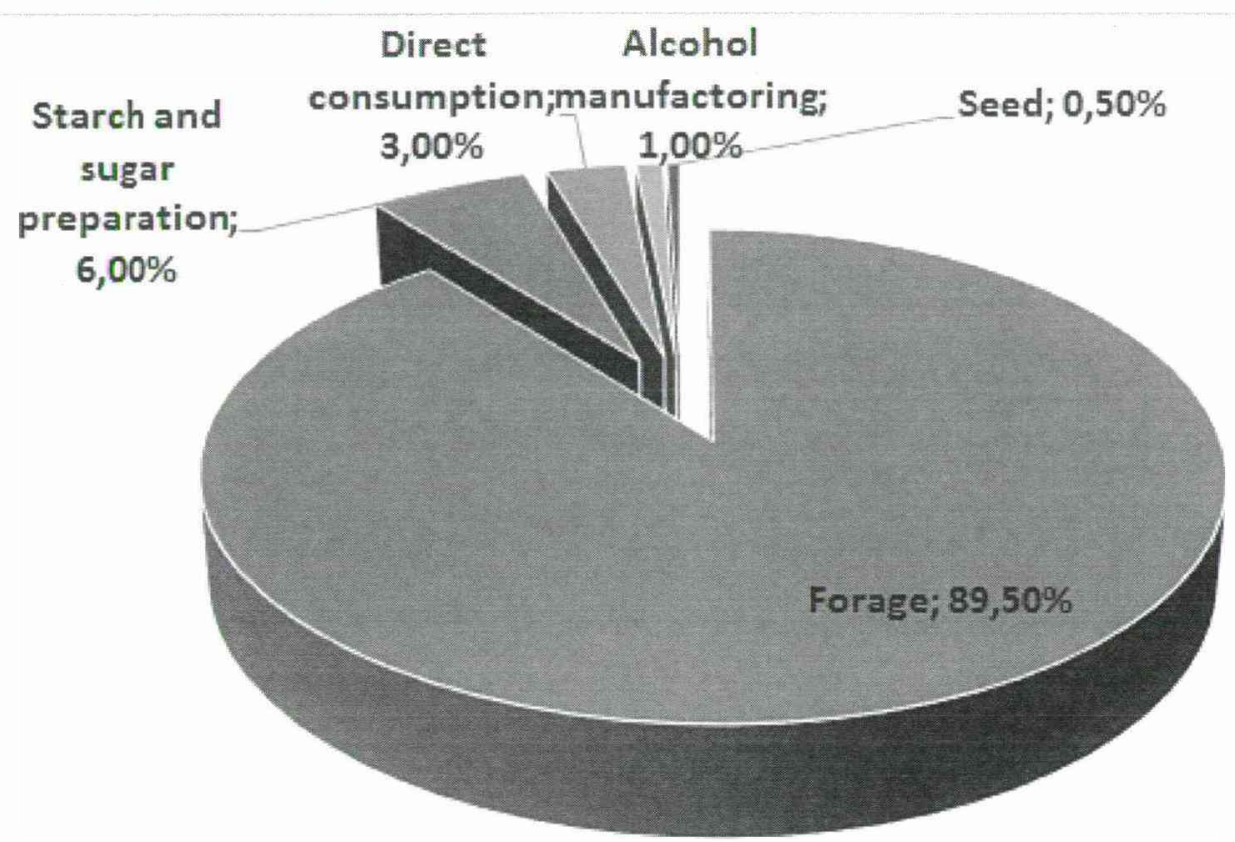

Figure 2. Corn Utilization in Hungary

Source: Györi, 2001

\section{MATERIAL AND METHOD}

Our investigations were carried out in Hungarian corn growing areas of the South Great Plain Region (Csongrád, Bács-Kiskun and Békés Counties) only. Qualitative research method was used with interviews in which our questions were grouped in themes and topics previously defined. The questions were asked directly from young farmers, who operated the farm, then we recorded and analysed the replies. The interviewees were mainly the leaders of already existing farms, run by young farmers, who have been operating for 1 to 5 years. The cost and income conditions were projected to one (1) hectare, without any fees and contributions, expressed as a net amount. Among the costs the land rental fees were not considered, as they are approximately the same as the value as the support provided with regard to the size of the area for producing a certain type of cultivated plant (TERA). The results thus obtained only apply to small farms (5-20 ha), since the size of the farms operated by young farmers were all within this value. There is no doubt that large farms can be managed more profitably, they have better bargain position in the purchase of inputs, and also significant savings show in fertilizer and diesel fuel use, and their profitability is reflected in less expenditures for transportation, drying and harvesting as well.

Specific costs for corn (silage, grain, sweet) the expected yield, the kind of rainfall, the green crop and the quality of the land were taken into account and they were analyzed by the following aspects taken into account: seeds, pesticides, fertilizer, diesel fuel, harvesting, transportation, cleaning / drying and wages.

The value of total expenditures for corn silage:

170-220 $000 \mathrm{HUF} / \mathrm{ha}$

The value of total expenditures for corn:

195-260 $000 \mathrm{HUF} / \mathrm{ha}$

The value of total expenditures for sweet corn:

(non-irrigated / irrigated) 
Evaluating the specific income conditions for the year of 2015 was not easy in case of young farmers, as in the case of silage corn it was clearly stated that it covered the mass feed needs of their animals, so it was not sold, in the case of grain corn exclusively the surplus was sold, while in the case of sweet corn they only produced for sale. None of them made itemized cost calculation.

Specific income value of silage corn:

$0 \mathrm{HUF} / \mathrm{ha}$

Specific income value of corn:

130-170 $000 \mathrm{HUF} / \mathrm{ha}$

Specific income value of

non-irrigated/irrigated corn:

$180000 / 250000 \mathrm{HUF} / \mathrm{ha}$

\section{RESULTS}

\section{Income generating capacity of corn}

The income producing ability of corn is expressed by a so-called EUME (European Units for Measurement) value derived from an SGM (Standard Gross Margin) value based on test farm income calculations. In the three-year 2007-2013 budget period in Hungary there were three tenders, while in 2014 and 2015 there were one tender each year, which were aimed to help start young farmers by up to $€ 40000$ HUF equivalent to $100 \%(90 \%+10$ \%) support. financed by European Agricultural Fund for Rural Development. Neither the 2014 (ANONIM, 2015a) nor the 2015 (ANONIM, 2015b) tenders offered extra points for undertaking the production of corn exclusively, in plant production the sector investigated in our research, therefore extra points were not provided to win the tender. Tenders offered extra points for the winning young farmer to undertake the task of changing the composition of the production by the end of the fourth year of the operating period so that $84-100 \%$ will be animal husbandry, horticulture, or the two of them together.

\section{The special situation of popcorn and sweet corn}

The data-base of the test farms, referring to the extremely diverse field of use of corn and cultivation specificity, counted/evaluated the income generating ability accordingly. Thus, there are separate categories (see Table 1) in SGM test base.

Table 1. The calculation of the income-generating capacity of corn based on SGM operational tests

\begin{tabular}{|l|l|c|c|}
\hline \multicolumn{1}{|c|}{ Code of item } & \multicolumn{1}{c|}{ Denomination } & Unit & SGM \\
\hline D06 & Grain corn & HUF/ha & 230541 \\
\hline D18B1 & $\begin{array}{l}\text { Forage crops - other green } \\
\text { fodder, silage corn }\end{array}$ & HUF/ha & 226031 \\
\hline D19 & $\begin{array}{l}\text { Reproduction material } \\
\text { (seeds and seedlings) }\end{array}$ & HUF/ha & 176674 \\
\hline D14A & $\begin{array}{l}\text { Fresh vegetables, melons, } \\
\text { strawberries - open field } \\
\text { and under low cover, } \\
\text { arable crop rotation }\end{array}$ & HUF/ha & 950331 \\
\hline
\end{tabular}

Source: Anonim, 2015b 
Considering the income-generating capacity there is not too much difference between the grain corn with D06 code, the silage corn with D18B1 code and the D19 coded corn grown for seed purposes, while the production of sweet corn and popcorn cultivation (D14a) is regarded as fresh vegetable cultivation, therefore it has extremely high SGM value compared to the other corn sectors. None of the young farmers in our research produced seed corn, since their relatively small area of farming as well as the expected high isolation distances during cultivation did not allow that.

In addition to the fact that these two types of corn with D14a code have a high SGM value, and thus they have high profitability indicators, they are not included among the field crops. They belong to the horticultural sector. Consequently, the young farmers who undertake to include $84-100 \%$ of these high capital-intensive, cost-intensive cultivated plants into their production structure in the fourth year might receive significant additional scoring.

\section{The relations between the profitability and the capital requirements of corn}

The profitability tests usually analyse relations with some other categories. The most common and also one of the longest-studied correlations is the relationship between size and profitability. If the above relation is applied to agriculture, within that to arable crops and in this case to corn, then the large size ("Series Size") primarily applies to the production of grain corn, silage corn and corn seed; while ("specialization") refers to sweet corn and popcorn regarded belonging to the vegetable sector (MIZIK, 2004). Even with the help of the state subsidy programme called "Land for farmers" it is difficult for young farmers to purchase/lease land therefore the possibility of producing grain corn, silage corn and corn seed based on series size, as mentioned above, is limited at the beginning of the operation years. The production of sweet corn and popcorn, based on specialisation, provides better scoring and viability for young farmers although it is a higher capitalintensive investment because of tool requirement (irrigation) reasons.

The relationship between concentration and profitability is also a frequently studied context. Economically it is accepted that the higher concentrations are associated with higher profitability. In terms of corn production a more modern generation of young farmers are characterized by a powerful concentration.

There is an interesting theoretical relationship between young farmers' profitability and financial situation. From the creditors' side one essential condition for the return is the profitable operation, however on the other hand borrowing can be intended to create a profitable operation is (for example, by purchasing new technology or equipment it can be said that the profitably working young farmer's debt level is lower and they have higher liquidity of stock (cash, marketable securities) than a non-profitable business partner. In case of sweet corn and popcorn production based on specialization with high investment needs the creditors cannot assess the long-term history of the young farmers because they get the "young farmers status "only" for five years. Therefore creditworthiness assessment can be made within this time period (MIZIK, 2004).

The direct and indirect agricultural subsidy system must also be mentioned that make difference between the corn production sectors in the 2014-2020 budget period, focusing on the development of labour intensive sectors. 


\section{CONCLUSIONS}

In case of the control at the end of the fourth year of the operating period the legislature must have recognized the relationship between corn production and consumption and as a result the income and capital demand conditions. This sector is a capital intensive, innovative sector that requires high concentration and professional knowledge, however the required input value is ensured on the long term by the diversity and marketability of the product offered for sale.

Through establishing an appropriate legislative background and scoring system for the tenders of young farmers it can surely be prevented that "forced corn growers" get among the candidates who do not consider the capital needs and income situation of crop production, as BENKÖ-KISS ET AL. (2010) also mentioned.

During the research it became clear that despite the progress achieved only a thin slice of the issue was discussed because of space limitations.

Other possible directions are many and diverse:

- Take into account other aspects; in case of different results explanations;

- extend the analysis for several years, strengthen the results and explore the different existing and potential trends (NAGY, 2012);

- analysis of the results by international standards could provide further valuable insights;

- a separate study could be prepared on the non-human factors that affect both the profitability and the need for capital;

- it would be wise to examine the impact of the tax system, of subsidies and deductions in the segments concerned.

Also it would be instructive to demonstrate the impact of education, within that the part of agricultural expertise on the performance of the company.

\section{REFERENCES}

ANONIM (2015a): A vidékfejlesztési miniszter 34/2014. (IV.4) VM rendelete az Európai Mezőgazdasági Vidékfejlesztési Alapból a fiatal mezőgazdasági termelök indításához a 2014. évben igényelhető támogatások részletes feltételeiről. Magyar Közlöny, 2015. 51.

ANONIM (2015b): A Miniszterelnökséget vezető miniszter 24/2015 (IV.28) MvM rendelete az Európai Mezőgazdasági Vidékfejlesztési Alapból a fiatal mezőgazdasági termelők indításához a 2015. évben igényelhető támogatások részletes feltételeiről Magyar Közlöny, 2015. 59.

ANTAL J. ET AL. (2005): Növénytermesztéstan alapjai, Növénytermesztéstan 1. Mezőgazda Kiadó Budapest, pp. 254-256.

BenKÖ-Kiss Á., BodnÁR K., Kis K., HoRvÁTH J. (2010): Preliminary investigation on innovation activity of agricultural ventures in South Great Plain Region in Hungary. Agrárés Vidékfejlesztési Szemle, 5(1): 220-225.

BENKÖ-KISS Á., BODNÁR K., KIS K., HoRVÁTH J. (2010): Agrárvállalkozások Innováció érzékenysége a Dél-alföldi Régióban, Szegedi Tudományegyetem Mezőgazdasági Kar, Kutatási jelentés, pp. 19.

MÁRTON L. (2013): Hagyományos és hidegtürő kukorica hibridek gyomnövényekkel való versengésének vizsgálata. PhD értekezés. Pannon Egyetem Georgikon Kar Keszthely Növénytermesztési és Kertészeti tudományok Doktori Iskola pp. 15. 
MıZIK T. (2004): Jövedelmezöség és versenyképesség a tesztüzemi rendszerben. $\mathrm{PhD}$ értekezés. Budapesti Corvinus Egyetem Agrárközgazdasági Ph.D program pp. 11-18.

NAGY L. (2012): A növénytermesztés szerkezetének optimalizálása a kockázatok figyelembe vételével. Agrárinformatika 3(2): 62.

FERENCSIK S. (2015): A kukorica hagyományos és csökkentett menetszámú talajmüvelési rendszereinek komplex elemzése. PhD értekezés, Debreceni Egyetem Kerpely Kálmán Doktori Iskola, pp. 8. 